\section{International Scientific Journal Theoretical \& Applied Science}

p-ISSN: 2308-4944 (print) e-ISSN: 2409-0085 (online)

Year: $2018 \quad$ Issue: $03 \quad$ Volume: 59

Published: $14.03 .2018 \quad \underline{\text { http://T-Science.org }}$
Qurat-ul-Ain Maqbool PMDC: 83188-P

Contribution: topic selection, Found additional resources of information.

Designation: Doctor in Bahawal victoria Hospital

Bahawalpur, Pakistan

Quratulainmaqbool4@gmail.com

Misbah Akbar

PMDC: 81982-P

Contribution: Data composing, data collection. Designation: Doctor in Jinnah Hospital Lahore, Pakistan Mibiyaakbar12@gmail.com

Rehana Bibi

PMDC: 83720-P

Contribution: data collection.

Designation: Doctor in Bahawal victoria Hospital

Bahawalpur, Pakistan

rehanahanif07@gmail.com

\title{
COMPARISON OF ANXIETY AND DEPRESSION AMONG FEMAL- POPULATIONS IN BAHAWALPUR AND MULTAN (TWO CITIES OF PAKISTAN)
}

\footnotetext{
Abstract: Objective: Objective of this study is the comparison of depression and anxiety among females of two cities of Pakistan, Bahawalpur and Multan.

Design: It is a cross-sectional design of study.

Place and duration of study: This study was conducted in bahawal victoria Hospital of bahawalpur and Nishtar Hospital of Multan city from first June 2016 to 31 May 2017.

Subjects and Methods: Those female patients were included who reported in psychiatry out door of the Hospital and falling in the criteria of ICD-10. Which patients had other diseases as well or having difficulty in communication, were excluded. Their somatic symptoms were written down. Two groups of cases were made, 60 cases from Bahawalpur reported in B.V Hospital and 60 cases from Multan reported in Nishtar hospital. Data collected from both groups was compared. Cases from Bahawalpur were tagged as group-1 and those from Multan as group- 2 .

Result: Following somatic symptoms were recorded in both groups, headache-group-1 65\%, group-2 $71 \%$, Pain in upper limbs and body in group-1\&2- $80 \%$ \& $90 \%$ respectively, constipation- $36 \%$ \& $25 \%$ respectively, suffocation $-18 \%$ and $22 \%$ respectively in both groups, joints pain- $30 \%$ \& 34\%, pain in abdomen $-20 \%$ \& $18 \%$, palpitation- $52 \%$ \& 45\%, giddiness- $28 \%$ \& 30\%, which are almost equal in both groups. Which symptoms are different in both groups 1 \& 2, include forehead pain $-52 \%$ \& 34\%, pain in temporal region-50\% \& $35 \%$, unilateral headache-28\% \& $12 \%$, chest pain- $20 \%$ and $50 \%$, dyspepsia-50\% and $80 \%$, hypo gastric pain $10 \%$ and $15 \%$ respectively in group -1 and group -2 .

Conclusion: somatic symptoms due to anxiety or depression are much usual in females of both cities. There is little difference between these two groups which may be due to different areas.

Key words: Female Populations, depression, anxiety, Bahawalpur, Multan

Language: English

Citation: Maqbool Q, Akbar M, Bibi R (2018) COMPARISON OF ANXIETY AND DEPRESSION AMONG FEMAL-POPULATIONS IN BAHAWALPUR AND MULTAN (TWO CITIES OF PAKISTAN). ISJ Theoretical \& Applied Science, 03 (59): 108-112.

Soi: http://s-o-i.org/1.1/TAS-03-59-15 Doi: crossef https://dx.doi.org/10.15863/TAS.2018.03.59.15
}

\section{INTRODUCTION}

Any psychological disease expresses itself via somatic signs and symptoms. Females of our country experience such types of psychological problems frequently which may be due to financial problems, family matters, stress of job or depression of studies etc. Most of these cases are illiterate. Treatment of such cases is difficult as they don't prefer to go to any psychologist doctor instead they go to hakeems or general practitioners. ${ }^{1}$ Mostly they are advised just 
symptomatic treatment and underlying disease is not addressed. So as a result patient is not cured and she is not satisfied so she goes to other one to investigate its problem and this way it costs too much without proper treatment. ${ }^{2}$ Underlying problem becomes worse and signs and new symptoms occur as disease goes on. ${ }^{3}$ Considering these points this study was done to determine frequency of such somatic problems due to psychological diseases and their comparison was done between two groups of females from two cities. Many studies have been done in the past about anxiety and depression in females and its expression as somatic symptoms. ${ }^{4}$ Our result is similar to the result of those studies. Presentation of the disease is different in different patients but most of the symptoms are same in all cases. Socioeconomic status and education are not the only factors of such somatic symptoms but many other factors play significant role as well. ${ }^{5}$ In developed countries such somatic problems are common despite good literacy rate and good economic status that proves there are some other elements which play a role causing mental illness in females. ${ }^{6}$

\section{SUBJECTS AND METHODS}

There is a fully working psychiatric ward in Bahawal Victoria Hospital of Bahawalpur city and also in Nishtar Hospital of Multan a well developed Psychiatry department is functional. In both hospitals the out patients average is in the range of 150-200 patients daily. This research was started on first June 2017. All those female patients were selected which fall in the criteria of ICD-10. The minimum age of the patient was 18 years and maximum was 50 years. Mean age of the females were 28 years. Most of the patients were either illiterate or just primary pass. Their socioeconomic status was low. Many of them belonged to poor family. Which patients were having other morbidities or did not understand Urdu language were also excluded from the study. All somatic symptoms were recorded. All cases were divided into two groups. In group-1 patients from Bahawalpur City were included and in Group-2 Patients from Multan were included. Both groups were compared with each other. In each group 60 cases were present. These were patients which were reported in out-doors of Bahawal victoria Hospital and Nishter Hospital. Both hospitals are well developed and well equipped with health facilities.

\section{RESULTS}

Somatic symptoms of anxiety and depression in females of both groups were compared in the form of tables as given below. Which symptoms were nearly same in both groups include following. In Group-1 and Group-2, generalized headache $-65 \%$ and $71 \%$ respectively, pain in joints- $30 \%$ and $34 \%$, abdominal pain- $20 \%$ and $18 \%$, constipation-36\% \& $25 \%$, palpitation- $52 \%$ \& $45 \%$, backache-50\% \& $52 \%$, giddiness- $28 \%$ \& $30 \%$ respectively. Which symptoms were different in Group-1 and Group-2 respectively include, frontal headache-52\% \& $34 \%$, bitemporal headache- $50 \% \& 35 \%$, heavy eyes$30 \% \& 10 \%$, chest pain-20\% \& 50\%, dyspepsia-50\% $\& 80 \%$ and generalized body pain- $70 \% \& 35 \%$.

Symptoms similar in both groups

Table-I

\begin{tabular}{|l|l|l|}
\hline PHYSICAL SYMPTOMS & GROUP-1 (\%) & GROUP-2 (\%) \\
\hline Pain in joints & 30 & 34 \\
\hline Difficulty in breathing & 18 & 22 \\
\hline Palpitation & 52 & 45 \\
\hline Sense of fatigue & 41 & 30 \\
\hline Altered bowel habits & 36 & 25 \\
\hline Generalized pain in the head & 65 & 71 \\
\hline Pain in upper limbs and upper body & 80 & 90 \\
\hline Pain in the abdomen & 20 & 18 \\
\hline Pain in backbone & 50 & 52 \\
\hline
\end{tabular}




\begin{tabular}{l|lr|ll|ll} 
& ISRA (India) & $=\mathbf{1 . 3 4 4}$ & SIS (USA) & $=\mathbf{0 . 9 1 2}$ & ICV (Poland) & $=\mathbf{6 . 6 3 0}$ \\
Impact Factor: & ISI (Dubai, UAE) $=\mathbf{0 . 8 2 9}$ & PUHЦ (Russia) $=\mathbf{0 . 2 0 7}$ & PIF (India) & $=\mathbf{1 . 9 4 0}$ \\
& GIF (Australia) & $\mathbf{0 . 5 6 4}$ & ESJI (KZ) & $=4.102$ & IBI (India) & $=\mathbf{4 . 2 6 0}$ \\
& JIF & $=\mathbf{1 . 5 0 0}$ & SJIF (Morocco) & $=\mathbf{2 . 0 3 1}$ & & \\
\hline
\end{tabular}

Physical symptoms different in two groups

Table-2

\begin{tabular}{|l|c|c|}
\hline PHYSICAL SYMPTOMS & GROUP-1 (\%) & GROUP-2 (\%) \\
\hline Dyspepsia & 50 & 80 \\
\hline Hypo gastric pain & 10 & 15 \\
\hline Chest pain & 20 & 50 \\
\hline Pain in half head & 28 & 12 \\
\hline Pain in both temporal regions & 50 & 35 \\
\hline Pain in the breast & 4 & 35 \\
\hline Pain in the whole body & 70 & 40 \\
\hline Heaviness of head & 60 & 10 \\
\hline Feeling of heaviness of eyes & 30 & 35 \\
\hline
\end{tabular}

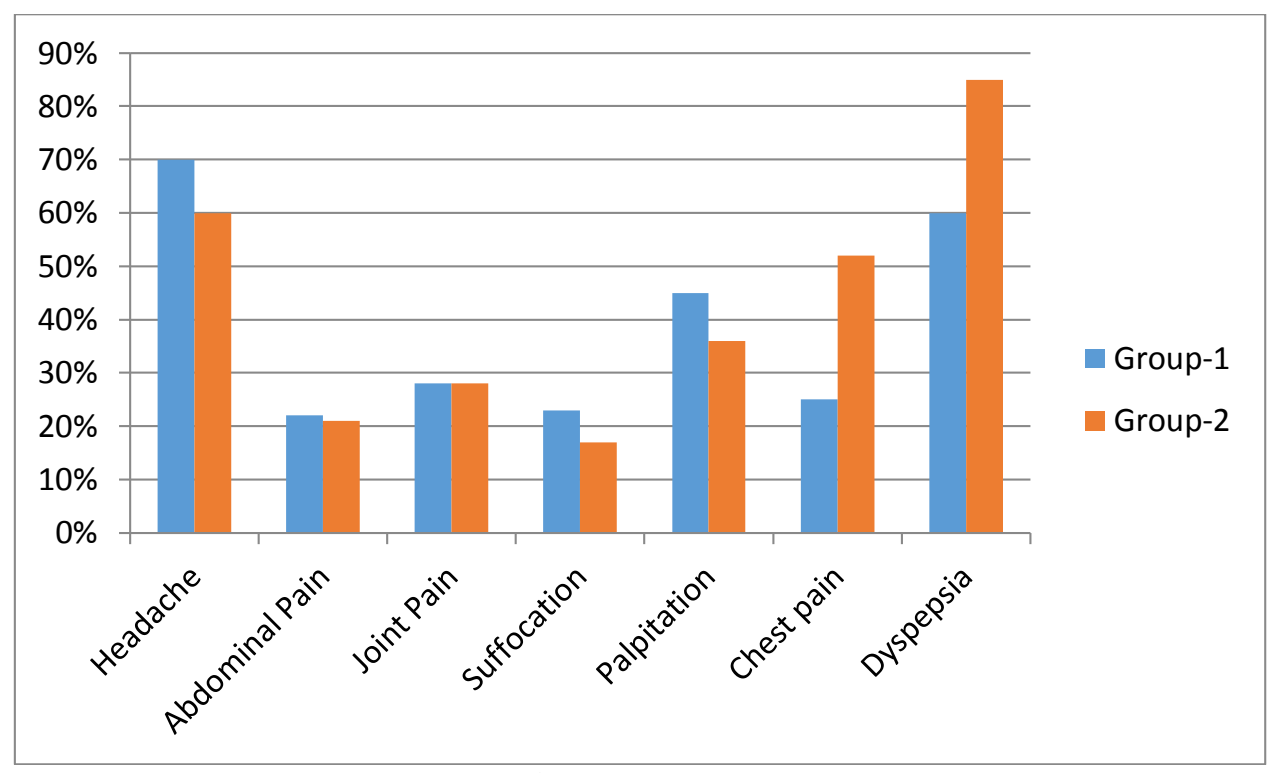

Picture 1 - Comparison of Somatic symptoms in Group-1 \& group-2.

\section{DISCUSSION}

Females from low socioeconomic status have more psychological illness than others. ${ }^{7}$ There was much similarity in somatic symptoms of two populations from different cities. There was also difference in few symptoms among two groups which was most probably due to socio-economic difference. Such as pain in neck and upper body, generalized headache, generalized weakness, backache, palpitation and easy fatigability are more common in the females of Bahawalpur and joint pain, suffocation and giddiness, central chest pain, dyspepsia are more common in females of Multan. It was observed that illiterate people were having more advance disease as compared to educated people. It is because uneducated females don't understand their psychological problems and don't treat them so disease goes on worsening. Even most of them don't consider it as a disease. ${ }^{8}$ In the past many related studies have been done. In 1996 Abu Arafehi and Russel $G$ determined relation between depression and abdominal pain in adults. ${ }^{9}$ Similar study done by 
Contello EJ and two others with him on mental illness in $1996 .{ }^{10}$ Hyams JS studied irritable bowel syndrome and abdominal pain in adult patients. ${ }^{11} \mathrm{~A}$ study done in 1981 in China by Achenbach TM. He studied depression in the people of China. According to his study $47 \%$ Chinese were suffering from depression. In 1991 and 1992 three scientists collected data of Five countries from WHO about somatic symptoms of people due to depression. Their result was $69 \%$ people were suffering from the illness. ${ }^{11}$ Another research done in 1991 and 1992 by Simon GE and Vonkorff et al. ${ }^{12}$ They determined association of somatization and mental distress. According to their result $49 \%$ people were having depression and $38 \%$ were suffering from anxiety. In 1989 Hamilton $\mathrm{M}$ did a study on symptoms of depression in patients. ${ }^{13}$ Other studies done on the same topic by Goldberg, Mumford, Tareen I.A.K concluded same results as this study done. ${ }^{14-18}$ In the light of all above studies it can be concluded that high percentage of people in western countries are suffering from mental illness despite very low rate of illiteracy. ${ }^{19}$ So it can be said that illiteracy and poor economic conditions are not the only factors of mental illness. There are many other factors of this problem as well. ${ }^{20-22}$

\section{CONCLUSION}

Somatic symptoms are very common problems with which people present in hospitals. Due to lack of diagnostic skills and facilities of treatment such people remain ignored. Due to limited resources our health institutions can not deal with these problems. There is requirement of further work in this aspect. It is necessary to create awareness in the people of our community and people related to medical profession so that such problems may be diagnosed and treated early. Medical professionals should be as much skilled to diagnose such patients and send them to psychologist or psychiatrist.

\section{References:}

1. Menninger, WC (1947) Psychosomaitc Medicine: Somatization Reaction. Psychosom Med. 1947; 9: 92-97.

2. White KL, William TF, Greenberg BG. (1961) The ecology of medical care N. Eng. J. Med 1961; 31: 62-64.

3. Kirmayer LJ. (1984) Culture, affect and somatization. Transcultural psychiatric review, 1984.

4. Wallen J. (1987) Psychiatric consultation in short term general hospitals. Arch. Psychiatry, 1987.

5. Stewar DE, Rashkin J. (1985) Psychiatric assessment of patients with 20th century disease. Can. Med. Assoc. J. 1985; 12: 48-51.

6. Escobar JI. (1987) Cross cultural aspects of somatization. Hospital community psychiatry, 1987; 28: 15-18.

7. Mechanic D. (1986) Concept of illness behaviour. Psychol Med. 1986; 21: 31-34.

8. Wilson DR, Widmer RB, et al. (1982) Somatic symptoms-a major feature of depression. J. Affective. Disord. 1982; 12: 95-98.

9. Abu-Arafeh I, Russes G (1996) Recurrent limb pain in school. Arch. Dis. Child 74; 336-339.

10. Contello EJ, Angold A, Burns BJ et al. (1996).

11. Hyams JS (1996), Abdominal pain and irritable bowel syndrome in adolescents: a community based study. J Pediatr. 129: 220-226.
12. Simon GE, Vonkorff Met at al. N Eng J Med 1999; 341: 1329-35 (43).

13. Hamilton M (1989) Frequency of symptoms in melancholia (depressive illness). Br. J of Psychiat. 154: 201-206.

14. Goldberg. DP and Bridges. K (1988) Somatic presentations of psychiatric illness in primary care setting. Journal of psycho-somatic research, 32: 134-44.

15. Mumford. D. B. (1989) Somatic sensations and psycholo9gical distress amongst students in Britain and Pakistan. Social Psychiatry and Psychiatric Epidemiology; 24: 321-326.

16. Mumford D. B, Bavington J. T, Bhatnagar K. S, Hussain Y, et al (1991). The Bradford Somatic Inventory. British Journal of Psychiatry; 158: 379-380.

17. Tareen I. A. K, Mumford D. B, Zahid M. A, Karim Mumford D. B, Devereux T. A, Moddy P. J, Jhonston J. V. (1991). Factors leading to the reporting of "functional" somatic symptoms by the general practice attendars. British Journal of Gen-Pract. 41: 454-458.

18. Mumford D. B, Tareen I. A. K, Bhatti M. R, Bajwa M. A, Ayub M, Pervaiz T. (1990). An investigations of "functional somatic symptoms" among patients attending hospital medical clinics in Pakistan. Using somatic symptoms to identify patients with psychiatric 


\begin{tabular}{l|lr|ll|ll} 
& ISRA (India) & $=\mathbf{1 . 3 4 4}$ & SIS (USA) & $=\mathbf{0 . 9 1 2}$ & ICV (Poland) & $=\mathbf{6 . 6 3 0}$ \\
Impact Factor: & ISI (Dubai, UAE) $=\mathbf{0 . 8 2 9}$ & PUHЦ (Russia) $=\mathbf{0 . 2 0 7}$ & PIF (India) & $=\mathbf{1 . 9 4 0}$ \\
& GIF (Australia) & $\mathbf{0 . 5 6 4}$ & ESJI (KZ) & $=4.102$ & IBI (India) & $=\mathbf{4 . 2 6 0}$ \\
& JIF & $=\mathbf{1 . 5 0 0}$ & SJIF (Morocco) & $=\mathbf{2 . 0 3 1}$ & & \\
\hline
\end{tabular}

disorders. Journal of Psychosomatic Research, vol. 35: 257-264.

19. Mumford D. B, Nazir M, Jelani F. U. M, Baig I. Y. (1990). Stress and psychiatric disorders in Hindu Kush. A community survey of mountain village in Chitral, Pakistan. British Journal of Psychiatry; 168: 299-307.
20. Mumford D. B. (1993). Somatization-a transcultural perspective. International review of psychiatry; 5: 231-242.

21. Mumford D. B, Saeed k. Ahmad, Imtiaz, Latif Shaia, Mubashar (1997). Stress and Psychiatric Disorders in Rural Punjab. A community survey. British Journal of Psychiatry; 170: 273278 